\title{
METASOMATIC DIAMONDS IN ECLOGITE XENOLITHS: PETROLOGIC AND PHOTOGRAPHIC EVIDENCE
}

\author{
Zdslav V. Spetsius ${ }^{1}$ and Lawrence A.Taylor ${ }^{2}$
}

${ }^{1}$ Institute of Diamond Industry, ALROSA Co. Ltd, Mirny, Russia; ${ }^{2}$ Planetary Geosciences Institute, De-
partment of Geological Sciences, University of Tennessee, Knoxville,U.S.A.

\section{INTRODUCTION}

In past years, the source of diamonds was considered to be from the same melt that resulted in the kimberlite itself. As time went on and more studies were performed into the petrologic nature of kimberlites, it was discovered that many diamonds actually occurred in xenoliths carried from depths by the kimberlite. In fact, this evidence became so great that 15-20 years ago (e.g., Meyer, 1985), it was generally considered that kimberlite was simply the carrier of the diamonds that had originated in eclogitic and peridotitic rocks within the mantle. The single diamonds found in the kimberlite were considered to be simply broken-up and otherwise disaggregated portions of xenoliths, similar to the common xenocrysts of garnet and ilmenite in kimberlites. More recently, it has been argued that some portions of many diamonds (e.g., the outer, frosted, fibrous layers) are actually grown in the kimberlitic magma and that some micro-diamonds are possibly of the same origin (e.g., Boyd et al., 1994, Navon, 1999). In this paper, we will examine evidences both for and against the genesis of diamonds within kimberlite versus in mantle xenoliths.

An ancient origin for cratonic mantle beneath the Siberian and Kaapvaal cratons is supported by Re-Os and Sm-Nd model ages for eclogite and peridotite xenoliths (Pearson, 1999, 2000). The age of some diamondiferous eclogites from South Africa, Canada, and Yakutia ranges between 2.8-3.5 Ga. The ages of diamonds, based on the radiogenic ages of their inclusions (e.g., Pearson, 1999, 2000; Richardson et al., 1993, 1997), suggest that diamonds may have formed over a long period of Earth's history, especially diamonds of eclogitic paragenesis. The only reasonable explanation for these extended ages is that after the initial formation of the eclogites, the diamonds continued to grow by secondary metasomatic fluids. Although the diamonds may have begun to grow at these early times, they would seem to have only relatively recently terminated their growth with capture by the kimberlitic melt.

\section{SAMPLES AND METHODS}

More than 500 diamondiferous xenoliths, mostly of eclogites, have been recovered from kimberlites of the Yakutian province. This study is the result of visual examination of over 300 of these samples and detailed investigation of mineralogy, petrography, and geochemistry of about 100 diamondiferous eclogites from pipes Mir, Udachnaya, and Sytykanskaya. In order to evaluate possible relation of the diamond formation with the metasomatic processes, 20 samples of diamondiferous eclogites were cut by diamond saw into plates with the diamonds on their surface. In this manner, special plates were prepared from each xenolith. Each diamondiferous xenolith has had at least one polished section/plate made from it. The primary garnets and clinopyroxenes, as well as several of the secondary phases that surrounded the diamond crystals, were investigated by electron microprobe analyses. In addition, a special study of the in-situ diamonds in the xenoliths was conducted by X-ray tomography.

In order to address the process of growth of diamonds in their host eclogite xenoliths, analyses of the diamonds, their inclusions, and their host eclogite minerals was performed. Major- and minor-element chemistry of diamond inclusions and host eclogite minerals were obtained both with the Cameca SX-50 electron microprobe at the University of Tennessee and with the Superprobe JXA-8800R electron microprobe at ALROSA Co Ltd. (Mirny). Analytical conditions included an accelerating voltage of $15 \mathrm{keV}$, a beam current of $20 \mathrm{nA}$, beam size of $5 \mu \mathrm{m}$, and 20 second counting times for all elements. All analyses underwent a full ZAF correction.

Trace elements were determined in the minerals by laser Ablation ICP-MS (LAM) at the RSES of Australian National University, Canberra, with NIST 610 glass as an external standard and $\mathrm{Ca}$ as an internal standard; pit diameters were $40-50 \mu \mathrm{m}$. Trace-element concentrations in diamond inclusions were measured by secondary ion mass spectrometry (SIMS), using the Cameca IMS 4f at the University of New Mexico. The details of the operating conditions are given in Beard et al. (1996).

\section{RESULTS}

\section{PETROLOGY OF DIAMONDIFEROUS ECLOGITES}

With the detailed investigations of diamondiferous eclogites from pipes Mir, Udachnaya, and Sytykanskaya, a generalized list of the characteristic features of these rocks is presented below (Spetsius and Serenco, 1990; Spetsius, 1995; Snyder et al., 1995, 1997; Taylor et al., 1996, 1998, 2000, 2003a,b; Spetsius and Taylor, 2002). 

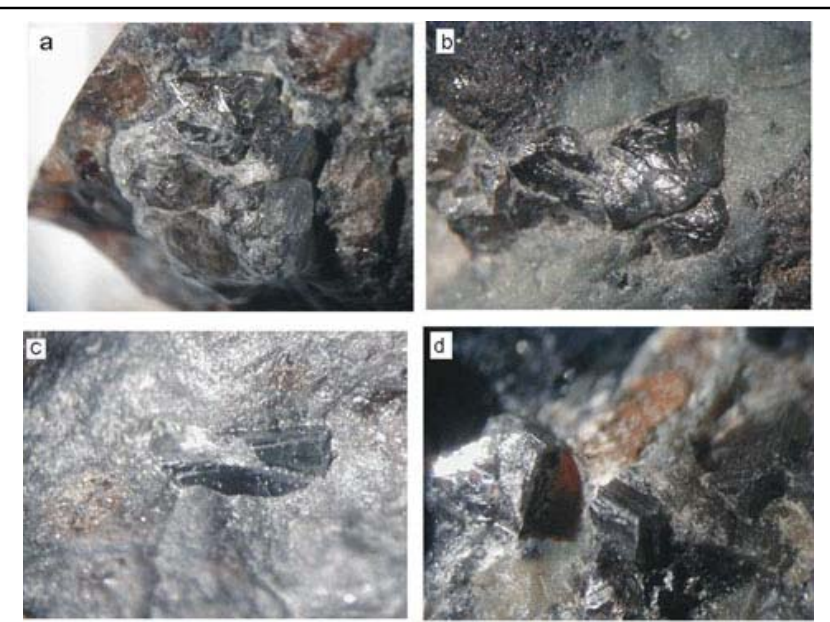

Figure 1. Photomicrographs of possible primary diamonds in eclogite xenoliths from the Udachnaya kimberlite pipe.

(a) Intergrowth of octahedral crystals between garnet grains; size of diamonds $=6 \mathrm{~mm}$; sample Ud-18. (b) Deformed octahedral diamonds in clinopyroxene. Notice the broken texture of one crystal that has been filled by clinopyroxene; size of diamonds $=5 \mathrm{~mm}$; sample Ud-45. (c) Partly deformed and broken diamond octahedron in an omphacite matrix, which also filled a crack in the diamond; long side of photograph $=10 \mathrm{~mm}$; sample Ud-220. (d) Octahedron divided into two parts by a vein filled with secondary minerals; size of diamond $=3.5 \mathrm{~mm}$; sample Ud-212.

1. All varieties of diamondiferous eclogitic xenoliths occur, including: bimineralic eclogites; kyanite-, corundum- and coesite-bearing eclogites, and garnet websterites.

2. Diamondiferous eclogites vary widely in the modal abundances of their primary minerals and also in the majorand trace-element chemistry of the whole rocks. Coarsegrained and medium-grained varieties of equigranular, as well as less-abundant mosaic-porphyritic texture, prevail among them; deformed varieties are also abundant. Ilmenite and graphite are distinguished as accessory minerals. Rutile and sulfides are common, with sulfide minerals being present in all eclogites, often associate with the diamonds.

3. The P-T estimates of the diamondiferous eclogites are essentially the same as those for all eclogites eclogites from kimberlites.

4. All eclogites, to greater or lesser extents, have experienced secondary partial melting (Spetsius and Taylor, 2002). This is a particular signature of diamondiferous eclogites, especially from pipes of the Daldyn-Alakytsky region (Spetsius and Serenco, 1990).

5. The trace-element contents of garnet and pyroxene in eclogites from Udachnaya demonstrate that xenoliths with diamonds are the same as in minerals from the general suite of eclogite rocks. Basically, most, if not all, geochemical characteristics of garnets and clinopyroxenes are similar between the diamondiferous and barren eclogites (Snyder et al., 1995, 1997; Spetsius et al., 1998; Taylor et al., 1998, 2000).

\section{DIAMONDS}

Diamonds in eclogites occur mainly as single crystals, and in unusually rich samples, there may be 1000 or more, albeit mostly microdiamonds. The size of the diamonds varies from hundreds of microns, up to 5 and rarely over $7 \mathrm{~mm}$. All varieties of morphologies occur, typical to kimberlitic eclogites. There are different growth patterns developed on the diamond crystals; however, forms typical of dissolution are never observed. As a rule, in one sample, diamonds have the same morphological habit, color, and size, though two morphologies of crystals can occur in the same xenolith. In many samples, diamonds have a regular octahedral forms and appear to have formed at or close to the time of formation of the eclogite minerals (Fig. 1).

Crystals of diamonds almost always are $100 \%$ preserved, except for the occasional deformation along glide-plane or when they are deformed and broken due to the deformation of the host xenoliths (Fig. $1 \mathrm{~b}, \mathrm{c}$ ). The distribution of diamonds in xenoliths is irregular and not confined to the surface of the samples. Based upon 3-dimensional tomography of diamondiferous eclogites, confirmed during our
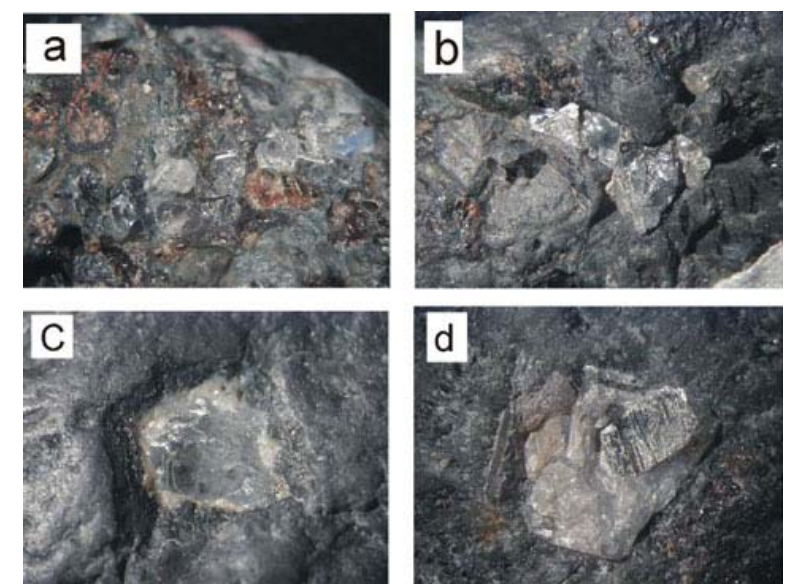

Figure 2. Examples of possible secondary origin of diamonds in eclogite xenoliths from the Udachnaya kimberlite pipe.

(a) Linear growth of six diamonds; long side of photograph $=25 \mathrm{~mm}$; sample Ud-205. (b) An irregular growth of diamonds between grains of rock-forming minerals; size of diamonds $=5$ mm; sample Ud-200. (c) Diamond octahedron surrounded by secondary vein products; size of diamond $=4 \mathrm{~mm}$; sample Ud-228. (d) Diamond with a complicated form, reflecting two obvious stages of growth. Notice on the outer side of crystal, the linear tiny plates of diamonds overgrowing into the surrounding minerals; size of diamond $=4.5 \mathrm{~mm}$; sample Ud-159. 
present study, Taylor et al. (2000) determined that in many xenoliths, there is a preferred direction of diamond alignment, sometimes almost linear, that corresponds to zones of intense development of partial-melt products and overall deformation (Fig. 2a). In rare samples, even large and well-developed, gem-quality octahedral crystals are surrounded by veins of secondary products (Fig. 2c). Typically for such situations, there are complicated crystals forms, with obvious evidence for multi-stage formation (Fig. 2d). Silicate mineral inclusions are not abundant in the eclogitic diamonds from eclogites, but sulfide minerals often occur.

In several of the eclogite xenoliths, mainly from the Udachnaya pipe, and to a lesser extent from pipe Sytykanskaya, there appears to be a distinct confinement of diamonds to zones of partial melting (Fig. 3). As shown by Spetsius (1999), diamonds occurring in the veins of partial melting products can be surrounded by incomplete rims of Mss, and segregations of pyrrhotite can be associated with the diamonds amongst the melt products. It should be emphasized that the diamonds in such cases are small $(<1$ $\mathrm{mm}$ ) and of cubic morphology.

There appear to be a relationship between diamond morphology and the overall composition of its host eclogite. I particular, cubic diamonds are developed mainly in highaluminous varieties of Group $\mathrm{C}$ eclogites (Spetsius and Serenco, 1990). It seems that there is a lateral heterogeneity of diamond morphologies and populations from different pipes along a trend north to the south within a kimberlite province. There is a manifest in the presence of cubic diamonds in Udachnaya and other pipes of the DaldynoAlakitsky region and an absence of cubes from pipes of the Malo-Botuobinsky field (Spetsius, 1999).

\section{DISCUSSION}

\section{Multi-stage diamond formation}

Diamonds are xenocrysts in kimberlites, along with ilmenite, garnet, and zircon. But there are a number of contradictions, hard to explain, on the assumption that all these diamonds crystallized simultaneously with the other rockforming minerals of eclogites (Taylor et al., 2003). The complex and multi-staged history of growth is obvious for both P-type and E-type diamonds. Birefringence and cathodoluminescence investigations show that the majority of all diamonds grew in a multistage process. Complicated $\mathrm{Cl}$ patterns of the diamond stratigraphy display a period of initial nucleation and growth, followed by resorption, regrowth, plastic deformation, and regrowth, including the incorporation of mineral inclusions. It is reflected in the zonal growth stratigraphy of the diamonds, showing the effects of processes of resorption, deformation, and later regrowth. The investigation of large diamond crystals of octahedral shape has shown that their central zones could be of different morphologies: cube, round, cube-

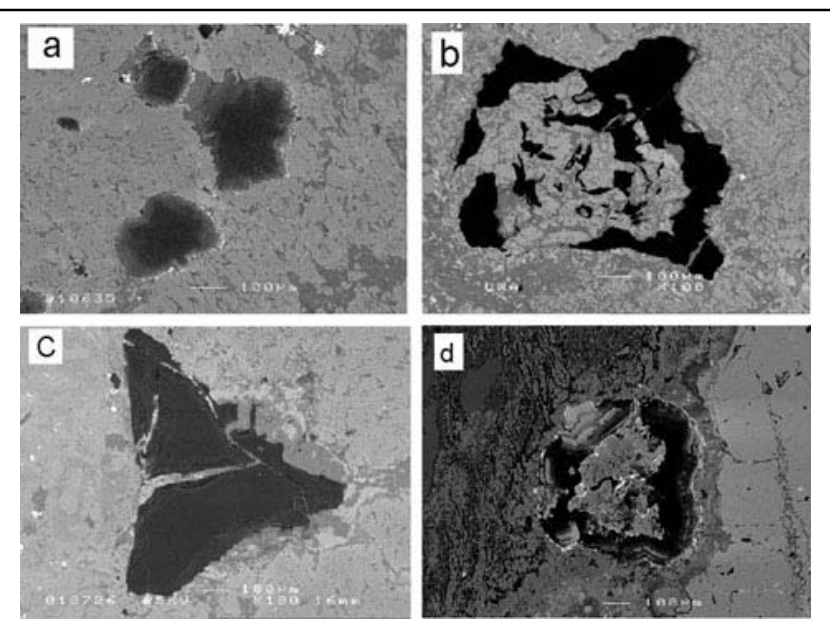

Figure 3. Diamonds associated with partial-melt products.

(a) Microdiamonds $(<1 \mathrm{~mm})$ in clinopyroxene partial-melt products (Sample Ud-24 in BSE + CL). (b) Diamond with the inclusion of secondary clinopyroxenes and other phases of partial-melt. Could be interpreted as indicating diamond resorption (Sample Ud-161 in BSE). (c) Slightly zoned diamond with cutting veins of partial-melt products in secondary clinopyroxenes (Sample U-388 in BSE + CL). (d) Zoned crystal of a hopper diamond with evidences for resorption by the partial melt, as located between the partially melted clinopyroxene, with 'spongy' texture, and garnet (Sample Ud-45 in BSE $+\mathrm{CL})$.

octahedron, or octahedron forms (e.g., Bulanova, 1995). The octahedral external crystal form may started with a central zone displaying a cubic-growth mode. Such complex stratigraphies provide evidence that diamonds have multistage, interrupted growths, in response to changing P$\mathrm{T}$ conditions and possible nutrient variations of the metasomatic fluids.

As outlined in Taylor et al. (2000), some petrologic evidences for multistage formations of diamonds are: 1) multiple DIs in one diamond with distinctly different chemistries; 2) large differences between DIs in adjacent crystals in eclogites; 3) sharp boundaries between zones having different nitrogen contents and aggregations; 4) large differences in $\delta^{13} \mathrm{C}$ and $\delta^{15} \mathrm{~N}$ in inner and outer parts of diamonds; 5) abundance of sulfide inclusions and heterogeneity of sulphur isotope compositions (Ruzicka et al, 1997); 6) finding of combined inclusions of eclogitic and peridotitic paragenesis in one crystal (Prinz et al., 1995); 7) large variations in $\mathrm{Pb}$ isotopic compositions of sulfides within a single diamond (Rudnick et al., 1993). Based upon Re-Os isotope age determinations of individual sulfide inclusions in diamonds from the Koffiefontein, Pearson et al. (1998) found that indicate two episodes of sulfide 
inclusion crystallization had occurred in the diamond, indicating at least two distinct ages of diamond formation.

\section{Metasomatic growth of diamonds}

Diamondiferous eclogites also contain petrographic indications interpreted as indicating that some diamonds postdate formation of the eclogite: a) a lack of diamonds within the primary garnets; b) the general observation that some diamonds are correlated with zones of deformation and alteration in many eclogites; c) the obvious resorption and possible growth features of diamonds in these alteration zones; d) metasomatic, partially-melted Cpx (spongy texture) in both the alteration zones and as inclusions in the diamonds (Taylor et al. (2002); Other indication of secondary diamond growth with relations to metasomatic processes are: a) occurrences of melted inclusions in diamonds from the Mir pipe and in cubic crystals from Zaire and Botswana (Bulanova et al., 1988; Navon et al., 1999); b) discovery of phlogopite and plagioclase in diamonds from the Monastery mine (Moore and Gurney, 1989); and c) finding of possible syngenetic inclusions of metasomatic minerals (Bulanova et al., 2003; Kopylova et al., 1988).

Based upon many of the facts and observation outlined and discussed above, it is possible to speculate on the formation of late-stage metasomatic diamond formation in some eclogites. Proof of this process can be seen in the distribution of diamond crystals within the products of partial melting. It is clearly seen that diamonds were grew around garnet that was already present, with some diamonds of a second generation being associated with kelyphite rims around garnets and the vein of partial-melt products in clinopyroxene (Spetsius, 1999; Spetsius and Taylor, 2002).

From an investigation of diamonds in eclogite xenoliths from Udachnaya, it was determined that, in rare samples, there are two different types of crystals, each with its own morphology, color, physical, and other features. These diamonds can be correlated with two growth generations, separated in time and with different P-T conditions (Spetsius, 1999). Large single crystals, mostly of octahedral habit, are thought to have formed probably under stable conditions and crystallized from a melt (Bulanova, 1995) simultaneously with the garnet and omphacite of the eclogites. This may be difficult to reconcile with the fact that the eclogites are basically metamorphic oceanic crust and have never gone through such a melt stage (Taylor et al., 2000). Perhaps an episode of growth from a metasomatic fluid would be more in order (Taylor et al., 1998). Such first generation diamonds in individual xenoliths exhibit signs of a complicated and torturous, subsequent history -- they may be deformed plastically, sometimes broken and resorbed (see Fig. 1).

The diamonds of the second generation are represented by cubes, coated crystals (probably only surface zones of these crystals), and microdiamonds. Coats on diamonds and cubes were formed by an abnormal mechanism of growth under conditions with a high degree of carbon super-saturation. Such condition may be realized during the last stages of partial melting when the melt is possibly enriched in carbon. This may have been aided by the sudden surge of carbonatitic fluids often preceding and accompanying kimberlite formation. It is likely that these diamonds grew at lower P-T conditions, near the time of kimberlite formation and eruption.

A relationship between the partial melting process and growth of such diamonds is conceivable. It is obvious that diamonds undergo multistage and interrupted growth, caused by changes in the chemical and P-T environment (e.g., Bulanova et al., 1999: Spetsius, 1995; Taylor et al., 1998). In particular, fibrous diamonds contain fluids that are highly enriched in $\mathrm{K}, \mathrm{Na}$, and other incompatible elements (Navon, 1999, and reference therein). These components would seem to be the same ones involved with the metasomatic fluids responsible for the partial melting of the eclogitic minerals. It is entirely possible that the rims of some of the diamonds in the partial-melt regions may have grown as a result of this melting process. Others diamonds, like cubes and microdiamonds, may have grown as a result of the metasomatic fluid penetrations.

There is an obvious distribution of second-generation diamonds in some eclogites (Spetsius, 1999), where microdiamonds are located along zones of partial-melting or kelyphite rims around garnet, as well as along general zones of major metasomatic alteration (Keller et al., 1999; Taylor et al., 2000). Such relations of diamonds in space have been found in eclogite xenoliths from Udachnaya, Sytykanskaya, and other Yakutian pipes. There are no unambiguous indications of the timing of this late-stage metasomatism and/or partial melting. However, interactions between diamonds and the partial melt are entirely possible, both with the stable and metastable growth of coatings, as well as resorption of diamonds, as well shown in Fig. 3d. It is proposed that some metasomatic growth of diamonds in eclogite xenoliths may have occurred at different times and connected with the late-stage partial melting event (Spetsius and Taylor, 2002. This process may take place at different intervals during mantle evolution, and in some cases, it was associated with fluid interactions that just preceded kimberlite eruption.

\section{CONCLUSIONS}

It is proposed that metasomatic growth of diamonds in eclogite xenoliths may have been closely associated with the metasomatism that caused some of the partial melting. This can occur both long before eruption deep in the mantle, as well as with kimberlite formation and eruption (e.g., fibrous-diamond growth on coated crystals). It is becoming increasingly obvious that the general understanding of the origin and formation of diamonds, although better constrained, is becoming ever more clouded. 


\section{REFERENCES}

Beard, B. L., Fraracci, K. N., Taylor, L. A., Snyder, G. A., Clayton, R. N., Mayeda, T., and Sobolev, N. V., 1996. Petrography and geochemistry of eclogites from the Mir kimberlite, Yakutia, Russia. Contrib. Mineral. Petrol., 125, 293-310.

Boyd, S.R., Pineau, F., and Javoy,M., 1994, Modelling the growth of natural diamonds. Chem. Geol. 116, 29-42.

Bulanova, G.P., 1995. The formation of diamond. J. Geochem. Explor., 53, 1-23.

Bulanova, G.P., Pearson, D.G., Hauri, E.H and Griffin, B.J., 2002. Carbon and nitrogen isotope systematics within a sector-growth diamond from the Mir kimberlite, Yakutia. Chem. Geol., 188, 105-123.

Bulanova, G.P., Muchemwa, E., Pearson, D.G., Griffin, B.J., Kelly, S.P., Klemme, S. and Smith, C.B., 2003. Syngenetic inclusions of yimengite in diamond from Sese kimberlite (Zimbabwe) - evidence for metasomatic conditions of growth. This volume.

Bulanova, G.P., Pearson, D.G., Hauri, E.H, Milledge H.G. and Barashkov Y.P., 2003. Dynamics of diamond growth: evidence from isotope and FTIR trends. This volume.

Deines, P., 1980. The carbon isotopic composition of diamonds: relationship to diamond shape, colour, occurrences and vapour composition. Geochim. Cosmochim. Acta, 44, 943-961.

Deines, P., Harris, J.W., Spear, P.M., Gurney, J.J. 1989. Nitrogen and $\delta^{13} \mathrm{C}$ content of Finch and Premier diamonds and their implications. Geochim. Cosmochim. Acta. 53, 1367-1378.

Hauri, E., Pearson, G., Bulanova, G.P. and Milledge, H.J., 1999. Microscopic variations in $\mathrm{C}$ and $\mathrm{N}$ isotopes within mantle diamonds revealed by SIMS. The $7^{\text {th }}$ IKC proceeding, v. 1, pp. 341-347.

Keller, R.A., Taylor, L. A., Snyder, G.A., Sobolev, V. N., Carlson, W.D., Bezborodov, S.M. and Sobolev, N. V., 1999. Detailed pull-apart of a diamondiferous eclogite xenoliths: Implications for mantle processes during diamond genesis. The $7^{\text {th }}$ IKC proceeding, v.1, pp. 397-402.

Kinny, P.D., Trautman R.L., Griffin B.J., Fitzsimons, I.C.W. and Harte B. 1999. Carbon isotopic composition of microdiamonds . Proceeding $7^{\text {th }}$ International Kimberlite Conference. v.1, p. 429-436.

Kopylova, M.G., Rickard, R.S., Kleyenstueber, A., Taylor, W.R., Gurney, J.J, Daniels, L.R., 1997. First occurrence of strontian $\mathrm{K}-\mathrm{Cr}$ loparite and $\mathrm{Cr}$ chevkinite in diamonds. The $6^{\text {th }}$ IKC proceeding,, v. 2, , Russian Geology and Geophysics 38, 405-420.

Meyer, H.O.A.,1985. Genesis of diamond: A mantle saga. Amer. Mineral. 70, 344-355.

Navon, O. 1999. Diamond formation in the Earth's mantle. The $7^{\text {th }}$ IKC proceeding, v. 2, pp.584-605.

Pearson, D.G., Shirey, S.B., Bulanova, G.P., Carlson, R.W., Milledge, H.J., 1999. Re-Os isotope measurements of single sulphide inclusions in Siberian diamond and its nitrogen aggregation systematics. Geochim. Cosmochim. Acta., 63, 703-711.

Pearson D. G., Shirey S. B., Harris J. W., and Carlson R. W. (1998b) Sulfide inclusions in diamonds from the Koffiefontein kimberlite, S.Africa: constraints on diamond ages and mantle Re-Os systematics. Earth Planet. Sci. Lett. 160, 311-326.
Prinz, M., Manson, D.V., Hlava, P.F., and Kiel, K., 1975, Inclusions in diamonds: garnet lherzolite and eclogite assemblages: Phys. Chem. Earth, v. 9, p. 797-815.

Richardson, S. H., Harris, J. W. and Garney, J. J., 1993. Three generations of diamonds from old continental mantle. Nature, 366, 256-258.

Richardson, S.H., Chinn, I.L., and Harris, J.W., 1998. Age and origin of eclogitic diamonds from the Jwaneng kimberlite, Botswana. Ext. Abstr. $7^{\text {th }}$ International Kimberlite Conference, pp. 734-736.

Richardson. S. H., Gurney. J. J., Erlank. A. J. and Harris. J. W., 1984. Origin of diamonds in old enriched mantle. Nature, 310, 198-202.

Rudnick, R.L., Eldridge, C.S., and Bulanova, G.P., 1993, Diamond growth history from in situ measurements of $\mathrm{Pb}$ and $\mathrm{S}$ isotopic compositions of sulphide inclusions. Geology 21, 13-16.y

Ruzicka, A., L.R. Riciputi, J. Greenwood, L.A. Taylor, G.A. Snyder, R.A. Keller, G.P. Bulanova, and H.J. Millidge, 1999, Petrogenesis of mantle-derived sulfide inclusions in Yakutian diamonds: Chemical and Isotopic disequilibrium during quenching from high temperatures, Proc. $7^{\text {th }}$ Int'l Kimberlite Conf., Vol. 2, Editors Gurney, Gurney, Pascoe, \& Richardson, National Printers, So. Afr.,741-749.

Snyder, G.A., Taylor, L.A., Jerde, E.A., Clayton, R.N., Mayeda, T.K., Deines, P., Rossman, G.R., and Sobolev, N.V., 1995, Archean mantle heterogeneity and the origin of diamondiferous eclogites, Siberia: Evidence from stable isotopes and hydroxyl in garnet: Amer. Mineral., v. 80, p. 799-809.

Snyder, G.A., Taylor, L.A., Crozaz, G., Halliday, A.N., Beard, B.L., Sobolev, V.N., and Sobolev, N.V., 1997, The origins of Yakutian eclogite xenoliths: Jour. Petrol., v. 38, p. $85-113$

Spetsius, Z. V., 1995. Diamondiferous eclogites from Yakutia: Evidence for a late and multistage formation of diamonds. Ext.Abstract of 6th Int.Kimberlite Conf., pp. 572-574.

Spetsius, Z.V., 1995. Occurrence of diamond in the mantle: a case study from the Siberian Platform. Journal of Geochemical Exploration 53, 25-39.

Spetsius, Z.V., 1999. Two generation of diamonds in the eclogite xenoliths. The $7^{\text {th }}$ IKC proceeding, v. 2, pp. 823-828.

Spetsius, Z.V. and Serenko, V.P., 1990. Composition of continental upper mantle and lower crust beneath the Siberian platform. Moscow: Nauka (in Russian).

Spetsius, Z.V., and Taylor, L.A., 2002, Partial melting in mantle eclogite xenoliths: Clues to microdiamond genesis. International Geology Review 44, 973-987.

Taylor, L.A., Milledge, H.J., Bulanova, G.P., Snyder, G.A. and Keller, R.A. 1998. Metasomatic eclogitic diamond growth: evidence from multiple diamond inclusions. Int. Geol. Rev. 40, 663-676.

Taylor, W.R., Bulanova, G.P., Milledge, H.J., 1995. Quantitative nitrogen aggregation study of some Yakutian diamonds: constraints on the growth, thermal and deformation history of peridotitic and eclogitic diamonds. Ext. Abs. $6^{\text {th }}$ Int. Kimb. Conf., pp. 608-610.

Contact: Zdislav Spetsius, Institute of Diamond Industry, Lenin St. 39, Mirny, Yakutia, 678170, Russia, Email: Spetsius@yna.alrosa-mir.ru 